\title{
Labour Taxation and its Effect on Employment Growth: Latest Estimations with Focus on the Czech Republic
}

\author{
Lucie Kábelová - Ondřej Bayer
}

\begin{abstract}
:
The paper aims to assess effects of the tax wedge on the employment rate in the Czech Republic. To investigate the impact of the tax wedge on the employment growth, we used a one-equation cointegration model based on the Engle-Granger theorem on OECD data. The results are surprising, because of an unexpected positive relationship between endogenous and exogenous variables. The paper itself is divided into five main parts. The first part is an introduction to the topic and a review of the literature, the second part is on data, the third part is on the statistical methodology and the last two parts cover results and the final conclusion.
\end{abstract}

Key words: Personal income tax; Tax wedge; Employment growth.

JEL classification: J30, J38, H24.

\section{Introduction}

Labour taxation and its impact on the labour market has been a topic of several studies and discussions in recent years. The existing literature argues that high taxes reduce economic activity (Rosen, 2005) and that labour taxation has a negative effect on labour supply and labour demand, see, for example, (Nickell, 2003), (de Haan, et al., 2003), (OECD, 2006).

The topic of personal income taxation and tax burden on labour has been also very popular within the latest research. One way to measure the tax burden on labour is using the so-called tax wedge, which is also one of the indicators that OECD adopts. According to OECD, the tax wedge is calculated as a ratio between the amount of taxes paid by an employee and the corresponding total labour cost for the employer. (OECD, 2014). A similar definition can be found in existing literature as well, see, for example, (Dolenc, Vodopivec, 2005).

As stated by OECD, the total tax wedge in the Czech Republic was 42.8 per cent in 2017. This places the Czech Republic on the 8th place out of the 34 OECD countries. The average tax burden on labour is around 35.9 per cent in OECD.

\footnotetext{
Lucie Kábelová; University of Economics, Prague, Faculty of Finance and Accounting, Department of Public Finance, W. Churchill Sq. 4, 13067 Prague 3, Czech Republic, <lucie.kabelova@vse.cz>.

Ondřej Bayer; University of Economics, Prague, Faculty of Finance and Accounting, Department of Public Finance, W. Churchill Sq. 4, 13067 Prague 3, Czech Republic, <ondrej.bayer@vse.cz>. The article is processed as an output of the research project Public Finance in the Czech Republic and EU registered under the registration number F1/1/2016.
} 
Kábelová, L. - Bayer, O.: Labor Taxation and its Effect on Employment Growth: Latest Estimations with Focus on the Czech Republic.

Recently, some of the OECD member countries started to reduce the (average) tax wedge, namely - Austria, Belgium, Canada, Denmark, Finland, France, Hungary, Ireland, Israel, the Netherlands, New Zeeland, Portugal, Sweden, Turkey and the United Kingdom. All of these countries have reduced their tax wedge by more than 5 percentage points between 2000 and 2016. (OECD, 2017).

The size of the tax wedge can be considered as a key factor because it might affect (directly and indirectly) some other macroeconomic indicators. Often discussed is the impact of the size of the tax wedge on the level of employment and the willingness to work. Research shows that a higher level of taxation can reduce the willingness to work and employment. For example, (Baker, et al., 2005) concluded that raising the tax wedge brings down the real-income earnings of employees and thereby slowing down the real consumption. Other studies reported that lowering the labour rate as a production factor stimulates labour participation and increases employment. (Fiorito, Padrini, 2001).

One of the reviewed studies and completed by (Dobele, et al., 2014) discusses the different types of research done by other authors in the field of labour taxes and their effects on the labour market. Economic indicators affected by labour tax changes were aggregated as follows:

- rates of unemployment and employment, individuals' engagement (inactivity) in the labour market, number of hours worked, poverty and income inequality (Universita Bocconi, 2011),

- labour costs, net wages of employees, rates of unemployment and employment (Arpia, Carpone, 2004),

- number of hours worked, individuals' engagement in the labour market (Blundell (1995),

- rates of unemployment and employment, labour costs (Alesina, Perotti, 1994),

- labour costs (Padoa-Schioppa, 1992),

- unemployment rate (Planas, et al., 2007),

- unemployment rate, GDP (Daveri, Tabellini, 2000).

Some studies focused on the actual measurement of the impact of a change of the tax wedge on employment. Although the studies used different types of econometric models and were based on different panel datasets, a larger part of the studies shows a negative relationship between the tax wedge and employment. 


\section{Tab. 1 Effects of the tax wedge on the labour market}

\begin{tabular}{lll}
\hline Researchers & $\begin{array}{l}\text { Change of the tax wedge } \\
\text { (TW) }\end{array}$ & Characteristics of effects \\
\hline $\begin{array}{l}\text { Nickell and Loyard } \\
(1999)\end{array}$ & Decrease of TW by 5 p.p. & Decrease of unemployment by 13 p.p. \\
$\begin{array}{l}\text { Daveri, Tabellini } \\
(2000)\end{array}$ & Increase of TW by 10 p.p. & Decrease of labour input by 1-3 p.p. \\
$\begin{array}{l}\text { World Bank (2005) } \\
\text { Bassanini, Duval }\end{array}$ & Increase of TW by 10 p.p. & Increase of unemployment by 4 p.p. \\
$\begin{array}{l}\text { (2006) } \\
\text { Dolenc, Laprošek }\end{array}$ & Increase of TW by 1 p.p. & $\begin{array}{l}\text { Decrease of employment by 0.04 p.p. } \\
\text { (2010) }\end{array}$ \\
$\begin{array}{l}\text { Dolenc, Leprošek } \\
\text { (2012) }\end{array}$ & Increase of TW by 1 p.p. & $\begin{array}{l}\text { Decrease of employment by } 1.7 \text { p.p. } \\
\text { (low-wage workers) }\end{array}$ \\
\hline $\begin{array}{l}\text { Decrease of employment by } 2.5 \text { p.p. } \\
\text { (high-wage workers) }\end{array}$
\end{tabular}

Source: Reviewed studies and own procesing.

Table 1 displays an overview of the selected reviewed studies. The results prove that an increase/decrease of the tax wedge has an impact on the employment/unemployment rate. In other words, the previous research shows that a decrease of the tax wedge might lead to an increase of employment, respectively a decrease of unemployment, and vice versa, an increase of the tax wedge might lead to a decrease of employment, respectively increase of unemployment.

The aim of this paper is to discuss the tax wedge as an indicator explaining the tax burden on labour and to analyse the impact of the tax wedge on the employment rate in the Czech Republic. To achieve the chosen goal, the Engle-Granger theorems were used in a single-cointegration model. The procedure was based on a simple static regression of selected parameters and stationary residual tests of static regression residues.

The rest of the paper is structured as follows. Sections 2 and 3 present data and the methodology. Section 4 discusses results and Section 5 concludes and gives some relevant recommendations.

\section{Data}

This analysis uses a tax wedge indicator based on the measures of OECD methodology. The tax wedge is calculated as a ratio between the amount of taxes paid by an employee and the corresponding total labour cost for the employer (Dolenc, Laprošek, 2012): 
Kábelová, L. - Bayer, O.: Labor Taxation and its Effect on Employment Growth: Latest Estimations with Focus on the Czech Republic.

$$
A T W=\frac{P I T+S S C e+S S C f+P T-C E}{w+P I T+S S C e+S S C f+P T}
$$

where ATW is the average tax wedge, PIT means personal income tax, SSCe stands for social security contributions paid by employees, SSCf represents social security contributions paid by employers, PT is used for payroll tax paid by employees, CB are cash benefits and w means the net wage.

OECD's current methodology constructs the tax wedge for eight types of taxpayers, defined as: single individual with no children and earnings at 67, 100 and $167 \%$ of average earnings, single worker with two children receiving $67 \%$ of average earnings, one-earner married couple with two children at $100 \%$ of average earnings, two-earner married couple, one at $100 \%$ of average earnings and the other at $33 \%$ or $67 \%$ (two children), two-earner married couple, one at $100 \%$ of average earnings and the other at $33 \%$ (no child).

For simplicity and clarity of the model, the three types of taxpayers (workers) were used in this analysis as an explanatory variable: single worker with no children and earnings at $67 \%$ of average earnings (CZ_67), single worker with no children and earnings at $100 \%$ of average earnings (CZ_100), single worker with no children and earnings at $167 \%$ of average earnings (CZ_167).

As a dependent variable, the employment rate was used (CZ_ER). Figure 1 shows the rate of employment in the Czech Republic for years 2000 - 2016. Note the specific trend shifts in 2004, 2008 and 2010. These shifts could be a problem in terms of stationarity of this variable. 
Fig. 1 The employment rate in the Czech Republic (2000 - 2016)

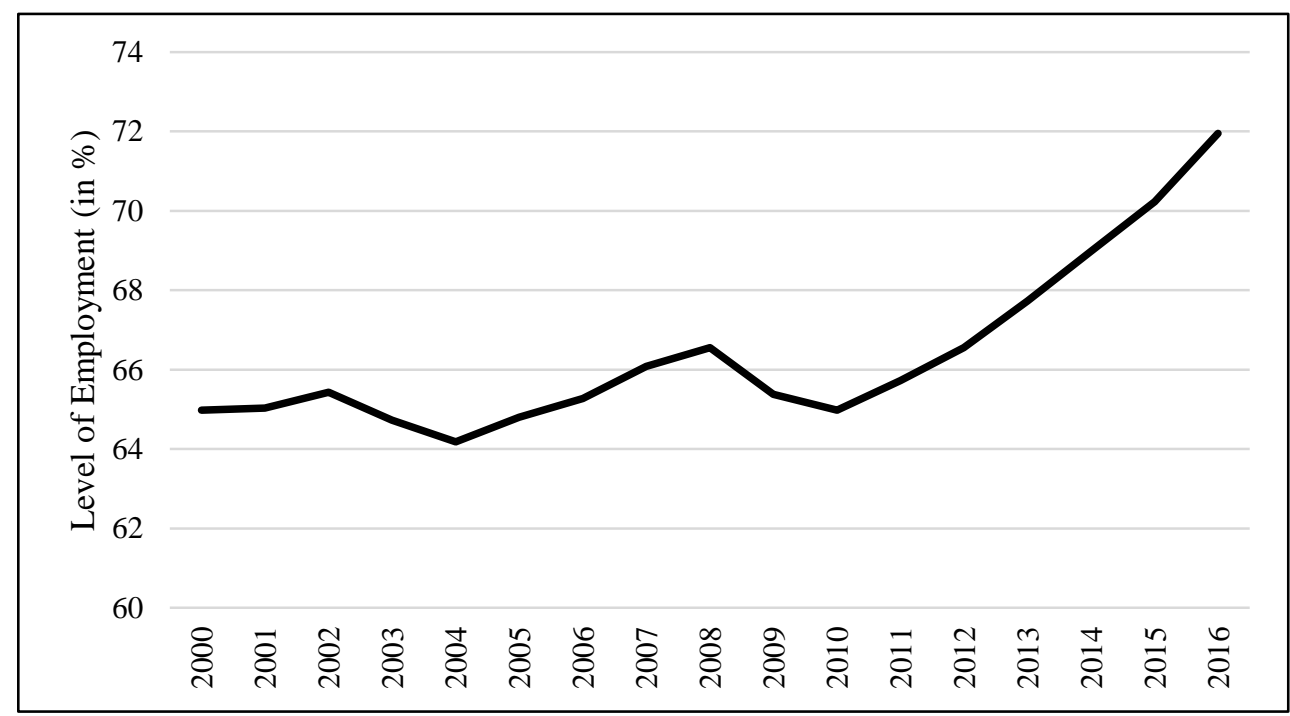

Source: OECD, own calculations.

As a controlling variable was adopted the unemployment rate (CZ_UR), because it is clear that employment and unemployment have a negative relationship.

\section{Methodology}

In order to reach the chosen goal, the Engle-Granger theorem was used in a oneequation cointegration model. PcGive statistical software was used to calculate the model. Methodology description is based on Arlt and Arltová (2009) and Bayer (2017).

The basic premise of the chosen method is the use of non-stationary original time series and testing their common order of integration and long-term relationship.

The procedure itself is based on designing a simple static regression of the selected variables and testing the static regression residue. The Engle-Granger theorem generally states that if residuals of a static regression are stationary, there is a longterm equilibrium relationship between the observed variables. The static regression analysis itself needs to be tested diagnostically in order to avoid bias due to the potential violation of the Gauss-Mark (GM) assumptions about the nonsystematic component of the model.

\subsection{Engle-Granger theorem}

This procedure is based on the principle that non-stationary time series can be cointegrated if the residues of their static regression are stationary and the time 
Kábelová, L. - Bayer, O.: Labor Taxation and its Effect on Employment Growth: Latest Estimations with Focus on the Czech Republic.

series have the same order of stationarity ${ }^{1}$. Assuming that $Y_{t}$ and $X_{t}$ are I(1), the cointegration of these series can be demonstrated if: $Z_{t}=\alpha X_{t}+\beta Y_{t} \sim I(0)$. The Engle-Granger theorem is based on the static regression:

$$
\mathrm{Y}_{\mathrm{t}}=\beta_{0}+\beta_{1} \mathrm{X}_{\mathrm{t}}+\alpha_{\mathrm{t}}
$$

From this equation we find out whether there is a stationary series common for $\mathrm{Y}$ and $\mathrm{X}$, since one can write:

$$
\widehat{\alpha}_{\mathrm{t}}=\mathrm{Y}_{\mathrm{t}}-\widehat{\beta}_{0}+\widehat{\beta}_{1} \mathrm{X}_{\mathrm{t}}
$$

Provided $\hat{u}_{t} \sim I(0)$, then $Y t$ and $X t$ are cointegrated. This process, however, presupposes that the non-systematic component $u_{t}$ has the character of white noise. Indeed, according to (Arlt and Arltová, 2009) one of three options may occur:

- $\alpha_{\mathrm{t}}$ is white noise, i.e. $\mathrm{I}(0)$,

- $\alpha_{t}$ is $I(0)$, but has a serial correlation, possibly exhibiting conditional heteroscedasticity, or

- $\alpha_{\mathrm{t}}$ is I $(1)$.

In the first case, estimates of the static regression alone are interpretations of the long-term relationship of the monitored time series.

In the latter case, it is possible to eliminate the issue of autocorrelation and conditional heteroscedasticity by dynamising the model to the $\operatorname{ADL}(p, q)$ model, which has the following general form:

$$
Y_{t}=c+\sum_{i=1}^{p} \alpha_{i} Y_{t-i}+\sum_{j=1}^{q} \beta_{j} X_{t-j}+a_{t}
$$

In the case of nonstationary residues, there is only a short-term relationship between the variables.

\subsection{Test of stationarity}

The first condition is a common order of integration of individual time series. For testing, the Augmented Dickey-Fuller test (ADF test) is used, which in this case takes the following form:

$$
\mathrm{X}_{\mathrm{t}}=\phi_{1} \mathrm{X}_{\mathrm{t}-1}+\sum_{\mathrm{i}=1}^{\mathrm{p}-1}\left(\gamma_{\mathrm{i}} \Delta \mathrm{X}_{\mathrm{t}-\mathrm{i}}\right)+\mathrm{a}_{\mathrm{t}},
$$

where $t$ is the time index, $\phi_{1}$ is the coefficient of a unit root, $\mathrm{p}$ is order of the AR process and $\mathrm{a}_{t}$ is the non-systematic component. The test hypothesis is as follows:

This is a simplification, because it is possible to work with rows of a different order of integration, but in the chosen case $\mathrm{I}(1)$ is sufficient. 
$H_{0}: \phi_{1}=1$, against $H_{1}:$ non $H_{0}$. The validity of the hypothesis is tested on the tadf distribution ${ }^{2}$.

The result of the stationary tests is as follows:

\section{Tab. 2 t-adf values for chosen variables}

\begin{tabular}{lrrrrr}
\hline & CZ_ER & CZ_100 & CZ_67 & CZ_167 & \multicolumn{1}{c}{ CZ_UR } \\
\hline Basic data & 2.141 & -2.396 & -1.571 & -1.489 & -0.847 \\
1st diff data & -0.936 & $-4.664 * *$ & $-3.966 * *$ & $-3.024 * *$ & $-2.369^{*}$ \\
\hline
\end{tabular}

Source: Data OECD (2018), own calculation.

Table 2 shows that all the explanatory variables are I(1), though there is a problem with the explanatory variable that is not stationary after the first difference at the chosen significance level. Due to several structural breaks of the explanatory variable (see Figure 1) and the relatively small number of observations, it is evident that the ADF test is biased by the presence of significant structural breaks. The actual course of the development in employment shows that it is a series with the order of integration I(1) and therefore it will be further kept in the model.

\subsection{Multicollinearity}

Given the chosen solution with more explanatory variables, it is important to test the GM assumption about the full rank of the explanatory variable matrix so that the model is not distorted by interrelations of the explanatory variables. A correlation matrix of variables is sufficient for the testing (Table 3).

\section{Tab. 3 Correlation matrix}

\begin{tabular}{lrrrrr}
\hline & CZ_ER & CZ_100 & CZ_67 & CZ_167 & CZ_UR \\
\hline CZ_ER & 1.000 & -0.077 & -0.374 & -0.172 & -0.774 \\
CZ_100 & -0.077 & 1.000 & 0.762 & 0.691 & -0.042 \\
CZ_67 & -0.374 & 0.762 & 1.000 & 0.445 & 0.451 \\
CZ_167 & -0.172 & 0.691 & 0.445 & 1.000 & -0.212 \\
CZ_UR & -0.774 & -0.042 & 0.451 & -0.212 & 1.000 \\
\hline
\end{tabular}

Source: Own calculations.

As stated in Table 3, the correlation coefficient reaches nowhere the critical level $(+/-0.8)$ and therefore it can be argued that the GM assumption is met.

2 Statistical significance level is displayed by $*$ convention, where $*$ means $5 \%$ significance level and $* *$ means $1 \%$ level of significance. 
Kábelová, L. - Bayer, O.: Labor Taxation and its Effect on Employment Growth: Latest Estimations with Focus on the Czech Republic.

\subsection{Autocorrelation}

By violation of the GM assumption about residual independence conditions, autocorrelation of the non-systematic component of the model occurs. To test the presence of autocorrelation, the Breusch-Godfrey test can be used (called the AR test in the output of PcGive). In case of a linear regression:

$$
\mathrm{Y}_{\mathrm{t}}=\mathrm{c}+\beta_{1} \mathrm{X}_{1 \mathrm{t}}+\beta_{2} \mathrm{X}_{2 \mathrm{t}}+\cdots+\beta_{\mathrm{i}} \mathrm{X}_{\mathrm{it}}+\mathrm{a}_{\mathrm{t}}
$$

The test is based on the assumption that the non-systematic component of a linear regression model can originate from $\operatorname{AR}(p)$ and may take the form of:

$$
a_{t}=\rho_{1} a_{t-1}+\rho_{2} a_{t-2}+\cdots+\rho_{p} a_{t-p}+e_{t}
$$

The estimated non-systematic component of the linear regression analysis model has the following form:

$$
\hat{a}_{t}=c+\beta_{1} X_{1 t}+\beta_{2} X_{2 t}+\cdots+\beta_{i} X_{i t}+\rho_{1} \hat{a}_{t-1}+\rho_{2} \hat{a}_{t-2}+\cdots+\rho_{p} \hat{a}_{t-p}+e_{t}
$$

Using the standard index of determination $\mathrm{R}^{2}$ it is possible to use the asymptotic approximation of $\chi^{2}$ statistics, when $n R^{2} \sim \chi_{p}^{2}$, where $n=T-p$, where $\mathrm{T}$ is the number of observation and $\mathrm{p}$ is the order of AR. The tested hypothesis is $\mathrm{H}_{0}: \rho_{1}=\rho_{2}=\ldots=\rho_{\mathrm{p}}=0$ against $\mathrm{H}_{1}:$ nonH $_{0}$.

In the case of autocorrelation, the model can be expanded to $\operatorname{ADL}(p, q)$ or a suitable dummy variable can be used.

\subsection{Heteroscedasticity}

In the event of a disruption of the constant dispersion condition of the nonsystematic component, heteroscedasticity occurs. The ARCH (AutoRegressive Conditional Heteroscedasticity) test is used for the testing. The test itself uses dynamic Quadratic Residue Testing in the following form:

$$
\hat{a}_{\mathrm{t}}^{2}=\mathrm{c}+\beta_{1} \hat{\mathrm{a}}_{\mathrm{t}-1}^{2}+\beta_{2} \hat{a}_{\mathrm{t}-2}^{2}+\cdots+\beta_{\mathrm{q}} \hat{a}_{\mathrm{t}-\mathrm{q}}^{2}+\mathrm{e}_{\mathrm{t}}
$$

Using the asymptotic approximation $n R^{2} \sim \chi_{q}^{2}$, where $n=T-p$, where $T$ is the number of observation and $p$ is the order of AR. The tested hypothesis is $\mathrm{H}_{0}: \beta_{0}=\beta_{1}=\ldots=\beta_{\mathrm{p}}=0$ against $\mathrm{H}_{1}:$ nonH $_{0}$.

Similarly to the autocorrelation, the problem of heteroscedasticity can be eliminated by dynamisation or by possible inclusion of a dummy variable.

\subsection{Normality}

The final test of the GM assumption is testing normality of the non-systematic component. In general, it can be argued that with a large enough number of observations, the non-systematic component will have a normal distribution. However, in the case of a smaller number of observations, it is advisable to use the modified Jarque-Bera test (JB). The actual test is based on the testing of skewness 
and kurtosis. The basic principle of the test is that the skewness of the normal distribution is equal to 0 , and kurtosis of the distribution is 3 . The derived test criterion takes the form:

$$
\mathrm{JB}=\mathrm{SK}^{2}+\mathrm{KU}^{2},
$$

where the test of skewness is

$$
\mathrm{SK}=\left(\frac{\mathrm{T}}{6}\right)^{\frac{1}{2}} \cdot \frac{\widehat{\mathrm{m}}_{3}}{\widehat{\mathrm{m}}_{2}^{3 / 2}}
$$

For kurtosis testing:

$$
\mathrm{KU}=\left(\frac{\mathrm{T}}{24}\right)^{\frac{1}{2}} \cdot\left(\frac{\widehat{\mathrm{m}}_{4}}{\widehat{\mathrm{m}}_{2}^{2}}-3\right),
$$

where $\widehat{m}_{i}=\frac{\sum_{t=1}^{T}\left(\widehat{u}_{t}-\bar{u}\right)^{i}}{T}$ for $\mathrm{i}=2,3,4 \ldots$

The zero hypothesis assumes a normal distribution of the non-systematic component. In case of the zero hypothesis's validity, the normality and obliquity normalised the normal $N(0,1)$ distribution. For hypothesis testing, we adopted the JB $\chi^{2}(2)$ statistic (Arlt and Arltová, 2009).

\section{Results and Discussion}

Once all the tests have been defined, it is possible to switch to the overall employment model in the Czech Republic and its dependency on the development of the tax wedge and the unemployment rate. The unemployment rate is used here as a control variable, while it is logical that overall employment and the unemployment rate have a negative relationship.

Static regression is:

Tab. 4 Static regression model for $C Z \_E R$

\begin{tabular}{lrrrrr}
\hline & Coefficient & \multicolumn{1}{c}{ Std.Error } & \multicolumn{1}{c}{ t-value } & t-prob & \multicolumn{1}{c}{ Part.R^2 } \\
\hline Constant & 85.6181 & 22.7600 & 3.7600 & 0.0027 & 0.5412 \\
CZ_100 & 1.7410 & 0.7089 & 2.4600 & 0.0303 & 0.3345 \\
CZ_167 & -1.8215 & 0.5324 & -3.4200 & 0.0051 & 0.4938 \\
CZ_UR & -1.6162 & 0.1917 & -8.4300 & 0.0000 & 0.8556 \\
D2008 & -3.5434 & 1.1430 & -3.1000 & 0.0092 & 0.4446 \\
\hline sigma & 0.9251 & RSS & 10.2700 & & \\
R^2 & 0.8611 & $\mathrm{~F}(4,12)$ & 18.6000 & {$[0.000]^{* *}$} & \\
Adj.R^2 & 0.8148 & & & & \\
\hline
\end{tabular}

Source: Own calculations. 
Kábelová, L. - Bayer, O.: Labor Taxation and its Effect on Employment Growth: Latest Estimations with Focus on the Czech Republic.

As Table 4 shows, the variables used did not produce a statistically significant tax wedge for the poorest, while the other variables are statistically significant - the dummy variable for 2008 (D2008) was used to offset the structural breaks of variables and to offset the main changes in the tax system (in 2008, the progressive taxation was changed to a linear taxation). The control variable shows that the model is logically correct.

The model residues are stationary and hence the long-term relationship between the variables is documented in the following Table 5:

\section{Tab. 5 ADF residual test}

\begin{tabular}{rlrlclll}
\hline D-lag & \multicolumn{1}{l}{ t-adf } & beta $\mathbf{Y}_{\mathbf{1}} \mathbf{1}$ & sigma & t-DY_lag & t-prob & AIC & F-prob \\
\hline 0 & $-2.812^{* *}$ & 0.3716 & 0.7133 & & -0.6152 & \\
\hline
\end{tabular}

Source: Own calculation.

Finally, the GM assumptions of the model must be tested using diagnostic tests the output of the PcGive statistical software is as follows (Table 6):

\section{Tab. 6 Diagnosis control}

\begin{tabular}{lllll}
\hline AR & test: & $\mathrm{F}(2,10)$ & 1.0743 & {$[0.3779]$} \\
ARCH & test: & $\mathrm{F}(1,15)$ & 0.9758 & {$[0.3389]$} \\
Normality & test: & $\mathrm{Chi}^{\wedge} 2(2)$ & 0.2766 & {$[0.8708]$} \\
Hetero & test: & $\mathrm{F}(6,9)$ & 1.1432 & {$[0.4111]$} \\
\hline
\end{tabular}

Source: Own calculation.

Diagnosis shows that all the GM assumptions are met and the model can, therefore, be overridden directly by the static regression and the deducted coefficients are long-term multipliers (Table 6). The model has the following form:

$$
\begin{gathered}
\widehat{\mathrm{CZER}}_{\mathrm{t}}=85.6181+1.741 \mathrm{CZ100} \mathrm{t}_{\mathrm{t}}-1.8215 \mathrm{CZ} 167_{\mathrm{t}}-1.6162 \mathrm{CZUR}_{\mathrm{t}} \\
-3.5434 \mathrm{D} 2008_{\mathrm{t}}
\end{gathered}
$$

The results are quite surprising. According to the reviewed sources and literature (see Introduction), the tax wedge should be negatively correlated with the employment rate. In this case, there is one variable (single worker with no children and earnings at $100 \%$ of average earnings) positively correlated and the other variable (single worker with no children and earnings at $167 \%$ of average earnings) negatively correlated (the control variable proves that the logic behind the model is correct).

The reason why the taxpayer with average wage has a positive correlation might be due to the fact that the level of taxpayer's taxation is not enough to change his or her willingness to work. The average worker with $167 \%$ of average wage is, in 
observatory years, negatively correlated because of his or her mobility. In other words, these workers are able to change their jobs more often and possibly work abroad. Workers with $67 \%$ of average wage are not statistically significant in this model, mainly because tax deductions almost cover the personal income tax. The dummy variable covers the complete tax reform in 2008, when the Czech Republic switched from the progressive taxation to a linear tax rate. If both tax variables are added up (there is assumption that both variables have the same weight), it is obvious that the tax wedge has a negative effect on employment. Overall, findings of the paper confirm that the reduction of the labour taxation might have a significant effect on the demand for labour and employment. According to the findings and recommendation of other studies (e.g. Dolenc, Laprošek, 2010) that the EU should continue with the trend of reducing the tax wedge, we recommend the same for the Czech Republic.

\section{Conclusion}

This paper analyses effects of the tax wedge on the employment rate in the Czech Republic. For that, the Engle-Granger theorems were used in a single-equation cointegration model. The findings indicate surprising results for one tax wedge, which is positively correlated with the employment rate. This phenomenon is based on the Czech system of tax deductions and the tax rate. Assuming the same weight of different tax wedges, the results are similar to those described in the literature. This paper is our first step into the research of a relationship between employment and tax wedges; further research will be focused on international comparison.

\section{References}

Alesina, A., Perotti, R., 1994. The welfare state and competitiveness. National Bureau of Economic Research. DOI: 10.3386/w4810.

Arlt, J., Arltová, M., 2009. Ekonomické časové řady. Professional Publishing, Praha.

Arpaia, A., Carone, G., 2004. Do labour taxes (and their composition) affect wages in the short and the long run? SSRN Electronic Journal. DOI: $10.2139 / \mathrm{ssrn} .871040 \mathrm{~h}$.

Baker, D. et al., 2005. Labor market institutions and unemployment: Assessment of the cross-country evidence. Fighting Unemployment 118, 72-118. DOI: 10.1093/0195165845.003.0003.

Bayer, O., 2017. It is possible to test similarity of tax system by econometric modelling? Proceedings of the 22nd International Conference Theoretical and Practical Aspects of Public Finance 2017, 7-13. 
Kábelová, L. - Bayer, O.: Labor Taxation and its Effect on Employment Growth: Latest Estimations with Focus on the Czech Republic.

Berger, T., Everaert, G., 2010. Labour taxes and unemployment evidence from a panel unobserved component model. Journal of Economic Dynamics and Control 34, 354-364. DOI: 10.1016/j.jedc.2009.09.010.

Blundell, R. W., 1995. The impact of taxation on labour force participation and labour supply. OECD Jobs Study Working Papers. DOI: 10.1787/576638686128.

Daveri, F., Tabellini, G., 2000. Unemployment, growth and taxation in industrial countries. Economic policy 15, 48-104. DOI: 10.1111/1468-0327.00057.

De Haan, J., Sturm, J. E., Volkerink, B., 2003. How to measure the tax burden on labour at the macro-level? CESifo Working Paper No. 963.

Dobele, L. et al., 2014. Theoretical Aspects of Labour Taxes and Their Effects on the Labour Market. Economic Science for Rural Development 33, 124-131.

Dolenc, P., Vodopivec, M., 2005. The tax wedge in Slovenia: international comparison and policy recommendation. Financial theory and practice 29, 229243.

Fiorito, R., Padrini, F., 2001. Distortionary taxation and labour market performance. Oxford Bulletin of Economics and Statistics 63, 173-196. DOI: 10.1111/1468-0084.00215.

International Monetary Fund (IMF), 2003. World Economic Outlook. Washington DC, USA. Available from: <http://www.imf.org/en/Publications/WEO/ Issues/2016/12/31/Transitions-Tensions>. [15 March 2018].

Nickell, S., 2003. Employment and taxes. CESifo Working Papers No. 1109.

Nickell, S, Nunziata, L., Ochel, W., 2005. Unemployment in the OECD since the 1960s. What do we know? The Economic Journal 115, 1-27. DOI: 10.1111/j.14680297.2004.00958.x.

Organisation for Economic Co-operation and Development (OECD), 2004. Taxing Wages 2002. Paris, France. Available from: <https://www.oecdilibrary.org/taxation/taxing-wages-2002_tax_wages-2002-en-fr>. [15 March 2018].

Organisation for Economic Co-operation and Development (OECD), 2003. Employment Outlook. Paris, France. Available from: <http://www.oecd.org/ els/employmentoutlook-previouseditions.htm>. [15 March 2018].

Organisation for Economic Co-operation and Development (OECD), 2017. Taxing Wages 2017, Paris, France. DOI: 10.1787/tax_wages-2017-en.

Padoa-Schioppa, F., 1992. Across-Country Analysis of the Tax-Push Hypothesis. Working Paper No. 11, International Monetary Fund. DOI: 10.5089/9781451925944.001. 
Planas, Ch., Roeger, W., Rossi, A., 2007. How much has labour taxation contributed to European structural unemployment? Journal of Economic Dynamics and Control 31, 1359-1375. DOI: 10.1016/j.jedc.2006.05.005.

Rosen, H. S., 2005. Public finance. McGraw-Hill Irwin, New York.

Racionero, M., 2013. The Economics of Taxation (Second edition), by Bernard Salanié (The MIT Press, Massachusetts Institute of Technology, Cambridge, 2011), pp. viii + 237. Economic Record 285, 276 - 278. DOI: 10.1111/14754932.12050.

Universita Bocconi, Center for research on the Public Sector, 2011. The role and Impact of Labour Taxation Policies, 248. 
